\title{
A STUDY ON AFFECTIVE WORK SKILLS NEEDS OF ENGINEERING AND TECHNOLOGY EDUCATION STUDENTS OF UNIVERSITIES IN NORTH CENTRAL STATES OF NIGERIA
}

\author{
Atsumbe, B.N and *Saba, T.M. \\ Industrial and Technology Education Department, Federal University of Technology Minna, \\ Niger State \\ *Correspondence Author
}

\begin{abstract}
The study is designed to investigate the affective work skills needs of Engineering and Technology Education students of universities in North Central States of Nigeria. A 18 items questionnaire was developed and used to collect data from 60 Engineers, 100 technicians and 150 lecturers. Purposive sampling techniques was used to get these respondents from industries and universities that offer Engineering and Technology Education programmes. Mean, standard deviation and one-way analysis of variance (ANOVA) at P<0.05 level of significant was used to analyse the data. Some of the findings include observing safety precautions when performing specific task, development of self-confidence and emotional stability on the machine, respecting other peoples opinion and loyal authorities, and developing positive work habit. It was recommended among others, that affective work skill, industrial safety, and occupational health education be in incorporated into the existing curriculum of Engineering and Technology base programmes.
\end{abstract}

Keywords: Affective work skills, Engineering, North Central, Technology

\section{INTRODUCTION}

One of the main purposes of Engineering and Technology Education programmes is to help individual students to develop desirable and affective work attitudes, acquire the necessary knowledge and skills of an occupation to enter and progress in the occupation. Supporting this view is Ogwo and Oranu (2006) who emphasized on the peculiar nature of vocational subjects, and that their nature requires the use of three brains or faculty - namely, physical, intellectual, and emotion brain. In other words in Engineering and Technology Education three domains, cognitive, affective and psychomotor are involved in the study. Affective work skills can be referred to as non technical abilities, employability skills and work ethic. These employability skills includes reading, problem solving, initiative skills and other skills like dependability, a positive attitude and other affective skills and traits. Petty (2006) sees work ethics as some sets of values based on the normal virtues of hard work and diligence. It is also a belief in moral benefit of work and its ability to enhance character. A work ethic may include being reliable, having initiative or maintaining social skills. Ogwo et al., (2006) described affective skills as ways of feeling and general behaviour, which reflect an individual's values, emotions, motives and interest.

FGN (2004) and Okoro (2006) noted that measurement of affective behaviour is currently receiving emphasis in Nigerian schools, for example the Federal Government of Nigeria in the national policy gave two affective objectives of Nigerian education. These are; the inculcation of national consciousness and national unity and the inculcation of the right type of values and attitudes for the survival of the individual and the Nigerian society. This is because education should lead not only to the acquisition of cognitive and psychomotor skills but also to the development of appropriate attitudes. Atsumbe (2002) while seriously advocating the need for technology education to teach affective work skills, stressed that any education that does not promote the right value and attitude to work, life and the society is of limited value. The teaching of appropriate values, attitudes and interest should form part of every well-organized Technology Education programme. Industrial Technology Educators must be continually vigilant and concerned about their students' (current and future teachers, trainers and engineers) understanding of knowledge and skills as well as the necessary occupational attitudes or the affective domain of behaviour (Petty, 1995).

Developing desirable work attitude is imperative for success in the world of work. This is so because industries where these graduates work, make use of complex machines, that require workers that are emotionally stable, workers that are obedient and are ready to take instructions from superiors. Miller and Usoro (1991) maintained that one of the major reasons why young men loose their jobs is as a result of poor attitudes to work and lack of work related interpersonal skills. Retreating the views of Miller and Usoro is Nelson (1997) who observed that several young technicians in America are thrown out of job not because they are not practically or theoretically unfit, rather because they lack manners and interpersonal skills. 
They further maintained that several of these young workers did come late to work, drunk and demonstrate a high level of stubbornness, as a result of this unruly behaviour many industries and factories are unable to meet what they call production target. Many young workers today lack these non-technical competencies that are associated with characteristics of occupation such as interpersonal relationship with peers and supervisors, work rules and job findings.

Based on the forgoing assertions the study is designed to seek the perception of engineers, technicians and lecturers on affective work skills required of Engineering and Technology Education students in North Central States of Nigerian universities.

\section{Research Question}

The following research question was postulated to guide the study.

1. What are the affective work skills needs of Engineering and Technology Education students of universities in North Central states of Nigeria?

\section{Hypothesis}

The following null hypotheses was formulated to guide the study and tested at 0.05 level of significance.

1. There will be no significant difference in the mean responses of Engineers, Technicians and Lecturers on the needed affective work skills needs of Engineering and Technology Education students of universities in North Central States of Nigeria.

\section{MATERIALS AND METHODS}

The design of the study is a survey research design. The study therefore sort the perception of engineers, technicians and lecturers on the affective work skills needs of Engineering and Technology Education students in Nigeria universities.

The study was carried out in the following North Central States: Benue, Kogi, Kwara, Niger and Plateau States. Universities offering Engineering and Technology Education and also industries in all the states mentioned served as the source for collecting data for the study.

The accessible population and target population for this study was made up of: All engineer and technicians in the industries and related organisations and all the lecturers in Engineering and Technology Education Departments in North Central
States universities. Purposive sampling technique was used to select 60 engineers, 100 technicians and 150 lecturers.

The questionnaire was administered to the respondents. A total of 310 copies of the questionnaire were administered and recovered. The data collected from the respondents were analysed using mean, standard deviation and One-Way Analysis of Variance (ANOVA). 2.50 was chosen as cut off point of mean, an item was regarded as required if its weighted mean was up to 2.50 and above and was considered not required, if the mean ratings was below 2.50. For testing the hypothesis if the value of the calculated $\mathrm{F}$ ratio was compared with $\mathrm{F}$ critical and null hypothesis was accepted if the value of $F$ ratio calculated is less or equal to $\mathrm{F}$ ratio and otherwise the null hypothesis rejected. Table value of $F$ was 3.04 at $P<0.05$.

\section{RESULTS}

Table 1 reveals that each of the 18 affective work skills needed by the Engineering and Technology Education students were rated by the respondents as required. The mean responses range from 3.31 3.76 , this signifies that these affective work skills are required for the programme hence they should form part of the curriculum, except for item 7 on close supervision.

\section{Hypothesis}

Table 2 It fails to reject hypothesis at $\mathrm{P}<0.05$ level significant meaning there is no significant difference in the mean ratings of Engineers, Technicians and Lecturers on the needed affective work skills needs of Engineering and Technology Education students of universities in North Central States, Nigeria.

\section{Findings}

- Observing safety precautions when performing specific task.

- $\quad$ Develop positive work habit.

- Develop creativity or initiative and make suggestion for job improvements.

- Develop self-confidence and be emotionally stable on the machine.

- Value time and be punctual to work

- $\quad$ Respect other peoples opinion and loyal to authorities.

- $\quad$ Recognize the value of neatness and keep the workshop neat. 
Table 1: Mean and Standard Deviation of Engineers, Technicians and Lecturers on the Affective Work skills Needs of Engineering and Technology Education Students in Universities of North Central States, Nigeria

\begin{tabular}{|c|c|c|c|c|c|c|c|c|c|c|}
\hline $\mathbf{S} / \mathbf{N}$ & Items & $\bar{X}_{1}$ & $\mathbf{S D}_{1}$ & $\bar{X}_{2}$ & $\mathbf{S D}_{2}$ & $\bar{X}_{3}$ & $\mathbf{S D}_{3}$ & $X_{t}$ & $\mathbf{S D}_{\mathrm{t}}$ & Remark \\
\hline 1 & $\begin{array}{l}\text { Observing safety precaution when performing } \\
\text { specific task }\end{array}$ & 3.52 & 1.28 & 3.20 & 1.03 & 3.53 & 1.23 & 3.42 & 1.27 & Required \\
\hline 2 & Develop positive work habit & 3.52 & 1.03 & 3.42 & 1.19 & 3.40 & 1.27 & 3.43 & 1.21 & Required \\
\hline 3 & Ability to get along with co-workers & 3.89 & 1.12 & 3.42 & 1.34 & 3.67 & 1.21 & 3.62 & 1.25 & Required \\
\hline 4 & Dependable when performing a given task & 3.43 & 1.12 & 3.37 & 1.36 & 3.63 & 1.20 & 3.51 & 1.24 & Required \\
\hline 5 & Effective management of time & 3.50 & 1.14 & 3.62 & 1.28 & 3.83 & 1.15 & 3.70 & 1.19 & Required \\
\hline 6 & $\begin{array}{l}\text { Appreciate the value of materials and consumables } \\
\text { and use them prudently }\end{array}$ & 2.93 & 1.12 & 3.26 & 1.15 & 3.48 & 1.21 & 3.31 & 1.19 & Required \\
\hline 7 & Working without close supervision in the workshop & 1.33 & 1.01 & 2.79 & 1.26 & 3.02 & 1.23 & 2.38 & 1.22 & $\begin{array}{l}\text { Not } \\
\text { Required }\end{array}$ \\
\hline 8 & $\begin{array}{l}\text { Develop creativity or initiative and make } \\
\text { suggestions for job improvement }\end{array}$ & 3.59 & 1.24 & 3.51 & 1.26 & 3.43 & 1.44 & 3.49 & 1.34 & Required \\
\hline 9 & Ability to listen and carry out instructions & 3.22 & 1.21 & 3.48 & 1.27 & 3.80 & 1.25 & 3.59 & 1.27 & Required \\
\hline 10 & Develop self confidence and be emotionally stable & 3.85 & 1.19 & 3.62 & 1.08 & 3.68 & 1.23 & 3.69 & 1.18 & Required \\
\hline 11 & Value time and be punctual to work & 3.57 & 1.09 & 3.41 & 1.29 & 3.94 & 1.14 & 3.70 & 1.21 & Required \\
\hline 12 & $\begin{array}{l}\text { Request other people's opinion and loyal to } \\
\text { supervisors }\end{array}$ & 3.50 & 1.17 & 3.62 & 1.15 & 3.82 & 1.15 & 3.70 & 1.16 & Required \\
\hline 13 & $\begin{array}{l}\text { Recognize the value of neatness and keep the } \\
\text { workshop neat }\end{array}$ & 3.37 & 1.25 & 3.32 & 1.14 & 3.75 & 1.16 & 3.54 & 1.18 & Required \\
\hline 14 & $\begin{array}{l}\text { Develop the habit of accuracy and efficiency when } \\
\text { working in the workshop }\end{array}$ & 3.57 & 1.22 & 3.41 & 1.11 & 3.94 & 1.09 & 3.70 & 1.14 & Required \\
\hline 15 & To be honest and trustworthy & 3.30 & 1.29 & 3.50 & 1.23 & 3.61 & 1.24 & 3.52 & 1.24 & Required \\
\hline 16 & Develop interest on the job & 3.57 & 1.00 & 3.56 & 1.18 & 3.98 & 1.11 & 3.76 & 1.13 & Required \\
\hline 17 & To be very hard working & 3.63 & 1.39 & 3.56 & 1.29 & 3.66 & 1.24 & 3.62 & 1.28 & Required \\
\hline 18 & $\begin{array}{l}\text { Develop positive maintenance culture in handling } \\
\text { tools ad equipment }\end{array}$ & 3.57 & 1.07 & 3.36 & 1.22 & 3.55 & 1.22 & 3.49 & 1.19 & Required \\
\hline \multicolumn{11}{|c|}{ Key: } \\
\hline \multicolumn{11}{|c|}{$\bar{X}_{1}=$ Mean responses of Engineers } \\
\hline \multicolumn{11}{|c|}{$\bar{X}_{2}=$ Mean responses of Technicians } \\
\hline$T$ & f & & & & & & & & & \\
\hline- & es & & & & & & & & & \\
\hline
\end{tabular}

Table 2: One - Way Analysis of Variance (ANOVA) for the Affective Work skills Needs of Engineering and Technology Education Students of Universities in North Central States, Nigeria

\begin{tabular}{lcccccc}
\hline $\begin{array}{l}\text { Source of } \\
\text { Variance }\end{array}$ & $\begin{array}{c}\text { Sum of } \\
\text { Square }\end{array}$ & df & $\begin{array}{c}\text { Mean } \\
\text { Square }\end{array}$ & f-ratio & f-value & Remarks \\
\hline Between & 0.5999 & 2 & 0.034 & & & Non- \\
Residual & 1.732 & 307 & 0.299 & 0.113 & 3.04 & Significant \\
Total & 2.331 & 309 & & & & \\
\hline
\end{tabular}

\section{DISCUSSION}

An examination of the results in Table 1 reveals that Engineering and Technology Education students in universities needed to be reinforced with sociopsychological factors of work known as affective work competencies or non-technical competencies. These were expressed by the three group of respondents, engineers, technicians and lecturers. They rated 17 out of 18 items as needed affective work skills required by Engineering and Technology Education students in Nigeria universities. The overall mean values obtained for this cluster ranged between 3.31 - 3.76 with the ability to observe safety precaution when performing specific task, having the highest mean value. This response is not coming as a surprise. This is because developing desirable work

This she substantiated by saying majority of industrial employers prefers engineers or technicians, who are attitudes is imperative for success in the world of work (Okoro, 2006). Research findings indicated that poor altitudes and lack of work related interpersonal skills are the main reason why young workers loose their jobs (Kimbell and Vineyard, 1975). They further expressed their views that affective work skills are more important for job survival than either cognitive or psychomotor skills.

The findings of this study is also in agreement with the work of Anyakoha (1990) who noted that punctuality to work; honesty; use of time to the best advantage; thoroughness and others are closely related to profit - a key to successful employment. In fact Anyakoha further explained that positive attitudes lead to higher productivity or job performance.

honest, reliable, dedicated responsive and free from all vices. The researchers are of the opinion that from 
this discussion, it may be reasoned that acquisition of affective skills, knowledge and work attitudes facilitates the employability of Engineering and Technology Education graduates. As a matter of fact no employer will want to engage engineers or technicians that are grossly deficient in the appropriate competencies or those that lack manners.

\section{CONCLUSION}

The universities have focused considerable attention on improved instruction of psychomotor skills and cognitive skills, but addressing area of affective work skills has been a special challenge to most who might have considered it. Affective Work skill is an attribute employer of labour desire of their employees to have optimal production. The Survival of our industries, and nation and to realized the vision 2020 , there is need therefore to incorporate affective skills into the particularly the curriculum of Nigerian universities offering Engineering and Technology base programmes.

\section{Recommendations}

\section{REFERENCES}

Anyakoha, E.U. (1990). Non-technical work competencies for home economics teachers in Nigeria. Nigeria Vocational Journal: 3, 16 21.

Atsumbe, B.N. (2002). Needed Improvements on the Curriculum of the Technical College Mechanical Engineering Craft Practice Curriculum. Unpublished Ph.D dissertation. Department of Vocational Teacher Education, University of Nigeria Nsukka.

Federal Republic of Nigeria (2004). National Policy on Education. Lagos, Nigeria: Federal Government press.

Kimbell, G. and Vineyard, B.S. (1975). Succeeding in the World of Work. Blooming, Illinois: McKnight publishing company.

Miller, W.R and Usoro, H.S. (1991). Effective work competencies as perceived by postsecondary vocational industrial technical students. Journal of Industrial Teacher Education. 18(3), $35-42$.
Based on the findings of this study the following recommendations were made:-

1. The identified affective work skills needs should be incorporated into existing curriculum immediately so that they can be used to prepare students who will fit into the labour market.

2. Industrial safety and occupational health education should be taught to students properly, that will help the Engineering and Technology Education graduates to be mindful of safety precautions while working in industry or related organisations.

3. Students of Engineering and Technology Education should be constantly exposed to sophisticated machines during the course of study to enable them develop self confidence and emotional stability when working on machines in industry.

4. University authorities should be mindful of unrulying behaviours in students and anyone found wanting or fails to obey school rules and regulations should be punished.

5. Students should be given opportunity to do their students Industrial Work Experience Scheme (SIWES) in industries and be given chance to handle machines.

Nelson, R.E. (1997). Survival Skills: Mastering the human aspects of work. American Vocational Journal. 52, $64-66$.

Ogwo, B.A. and Oranu, R.N. (2006). Methodology in Formal and Non-formal Technical/Vocational Education. Uwani Enugu: Ijejas printer and publishers company.

Okoro, O.M. (2006). Measurement and Evaluation in Education. Uruowulu - Obosi, Pacific publishers.

Okoro, O.M. (2006). Principles and Methods in Vocational and Technical Education. Nsukka, University press.

Petty, G.C. (1993). Affective work competencies of workers and supervisors from metal-working, building and construction, and maintenance/repair industries. Journal of Industrial Teacher Education. 21(1) 28 - 36.

Petty, G.C. (1995). Vocational - Technical Education and Occupational Work Ethic. Journal of Industrial Teacher Education. 32(3). 